\title{
EVALUASI POTENSI BAHAYA KESELAMATAN DAN KESEHATAN KERJA (K3) PADA PT. MMI - GRESIK
}

\author{
Muhammad Darmaji \\ Teknik Industri, Fakultas Teknik \\ Universitas Maarif Hasyim Latif, Sidoarjo, Indonesia \\ e-mail: aji100693@gmail.com
}

\begin{abstract}
ABSTRAK
PT. MMI merupakan perusahaan yang bergerak dibidang industri furniture kayu, pada saat ini telah menjadi perusahaan yang mengeskport produknya dengan tujuan eksport ke USA, perusahaan ini terletak di kabupaten Gresik, jawa timur. Proses produksinya banyak menggunakan alat dan mesin yang dapat menyebabkan kecelakaan kerja. Data perusahaan menunjukan terdapat 47 kasus kecelakaan kerja pada tahun 2016 - 2017 yang masing masing 22 kasus pada tahun 2016 dan 25 kasus pada tahun 2017. Dengan demikian perlu tindakan perbaikan guna menghindari terjadinya kerugian untuk perusahaan maupun pekerjanya. Dalam penelitian ini digunakan metode pendekatan yaitu metode Failure Mode and Effect Anlaysis (FMEA) dan kemudian dilanjutkan dengan metode Job Safety Analysis (JSA) . Berdasarkan perhitungan yang dilakukan dengan metode FMEA dengan RPN tertinggi yaitu 240 yaitu Terjepit Mesin Dengan effect failure mode Jari telunjuk robek dan hampir putus terjadi pada bagian Laminating, Untuk tertinggi kedua dengan nilai RPN 64 yaitu Tertimpa Bahan Baku (Kayu) terjadi pada bagian Saw timber. Sedangkan tertinggi ketiga dengan nilai rata - rata RPN 64 juga yaitu Tertimpa Barang (saat hendak memindahkannya) terjadi pada bagian Finishing. Tahapan selanjutnya menggunakan metode job safety analysis diperoleh 3 pekerjaan yang dianggap kritis yaitu pekerjaan pada bagian Saw Timber, Laminating, dan Finishing.
\end{abstract}

Kata Kunci : failure mode and effect analysis, job safety analysis, keselamatan dan kesehatan kerja.

\section{PENDAHULUAN}

PT. MMI merupakan perusahaan yang bergerak di bidang manufaktur Furniture yang memiliki pangsa pasar dengan tujuan eksport ke USA. PT. MMI sebenarnya sudah menerapkan sistem manajemen keselamatan dan kesehatan kerja (SMK3) yang baik. Namun, dalam proses produksinya sebagian besar masih saja terjadi beberapa kasus kecelakaan kerja yang berulang ulang dengan kejadian yang sama.

Menurut data kecelakaan kerja PT. MMI Tahun 2016 terdapat 22 kasus dan pada Tahun 2017 terdapat 25 kasus kecelakaan kerja. Dengan melihat adanya potensi bahaya serta penanganan kecelakaan kerja yang belum berjalan dengan baik, perusahaan ini memerlukan sebuah metode keselamatan dan kecelakaan kerja yang baik untuk menangani masalah ini. Metode Failure Mode and Effect Analysis (FMEA) sangat tepat untuk diterapkan karena metode ini didasarkan pada alasan bahwa FMEA merupakan suatu teknik yang dapat dipergunakan untuk melakukan analisis penyebab potensial timbulnya suatu gangguan, probabilitas kemunculan, dan bagaimana cara pendeteksian dari ganguan tersebut (Febri, 2011), setelah itu dilanjutkan dengan Metode Job Safety Analysis (JSA) sebagai upaya peningkatan dalam mengidentifikasi bahaya - bahaya yang terdapat dilingkungan kerja, beserta cara pengendalian atau penangulangan guna mencegah kecelakaan dan penyakit akibat kerja yang mungkin timbul dari suatu pekerjaan (Fauzi, 2009).

\section{METODE PENELITIAN}

Padapenelitian ini metode yang digunakan bersifat deskriptif, dan data yang diperoleh dari perusahaan dan dapat digunakan sebagai bahan penulisan laporan penelitian. Terdapat 3 tahapan yang akan dilakukan dalam pengolahan data hasil penelitian, berikut adalah penjelasan tahapan tahapan yang harus dilakukan :

\section{Menentukan jenis pekerjaan}

Menentukan jenis pekerjaan adalah langkah pertama dalam mengidentifikasi pekerjan yang dianggap kritis, dan mengacu pada faktor - faktor seperti potensi kecelakaan, frekuensi kecelakaan dan tingkat kecelakaan. 


\section{Mengidentifikasi bahaya masing - masing pekerjaan menggunakan metode Failure Mode and Effect Analysis (FMEA)}

Metode Failure Mode and Effect Analysis (FMEA) merupakan suatu metode keselamatan kerja yang digunakan untuk mengevalusi desain dari sistem yang ada dengan mempertimbangkan bermacam macam mode kegagalan dari sistem yang terdiri dari komponen dan menganalisis pengaruh pengaruhnya terhadap keandalan sistem tersebut (Siswanto, 2010).

Berikut ini adalah tahapan - tahapan dari metode Failure Mode and Effect Analysis (FMEA) :

a) Identifikasi pekerjaan.

b) Identifikasi failure mode potensial.

c) Identifikasi failure effect dan penyebabnya dari masalah potensial tersebut.

d) Menentukan nilai severity.

e) Menentuka nilai occurance.

f) Menentukan nilai detection.

g) Menghitung nilai Risk Priority Number (RPN) untuk menentukan prioritas tindakan yang tepat.

Langkah selanjutnya adalah mengidentifikasi potensi bahaya untuk menentukan akibat yang ditimbulkan dari masing - masing pekerjaan. Berdasarkan proses identifikasi tersebut, maka pada tahap ini pengembangan metode failure and effect analysis (FMEA) adalah meggunakan metode Job Safety Analysis (JSA) sebagai dasar untuk menentukan prioritas pekerjaan.

3. Pengolahan data selanjutnya melakukan langkah - langkah identifikasi menggunakan metode Job Safety Analysis (JSA)

Job Safety Analysis merupakan suatu metode analisis untuk menilai resiko serta mengidentifikasi tindakan - tindakan kontrol yang diperlukan untuk menghilangkan atau mengurangi resiko yang ada (Rijanto, 2010). Tujuan dari metode Job Safety Analysis (JSA) adalah untuk mengidentifikasi potensi bahaya disetiap aktivitas pekerjaan, sehingga tenaga kerja diharapkan mampu mengenali bahaya tersebut sebelum terjadi kecelakaan atau penyakit yang ditimbulkan akibat suatu pekerjaan.

Terdapat 4 langkah dasar yang harus dilakukan dalam mengembagkan pelaksanaan metode Job Safety Analysis (JSA) adalah sebagai berikut :

a) Menentukan jenis pekerjaan yang akan dianalisis.

b) Menguraikan pekerjaan menjadi langkah langkah dasar.

c) Mengidentifikasi bahaya pada masing masing pekerjaan

d) Mengendalikan bahaya keselamatan dan kesehatan kerja dengan cara mengembangkan prosedur kerja aman yang dapat dianjurkan untuk mencegah terjadinya suatu kecelakaan.

Data penelitian yang telah diperoleh kemudian dianalisis, dan dijadikan pedoman dalam melakukan perbaikan. Untuk perbaikan bisa berupa penyusunan instruksi kerja (IK) yang baru sehingga pekerja lebih memerhatikan aspek keselamatan kerja, selain itu faktor disiplin kerja juga perlu diperhatikan. Hal ini dilakukan untuk membuktikan apakah kasus kecelakaan kerja yang terjadi disebabkan oleh belum adanya perbaikan yang sesuai untuk masalah yang ada pada PT. MMI.

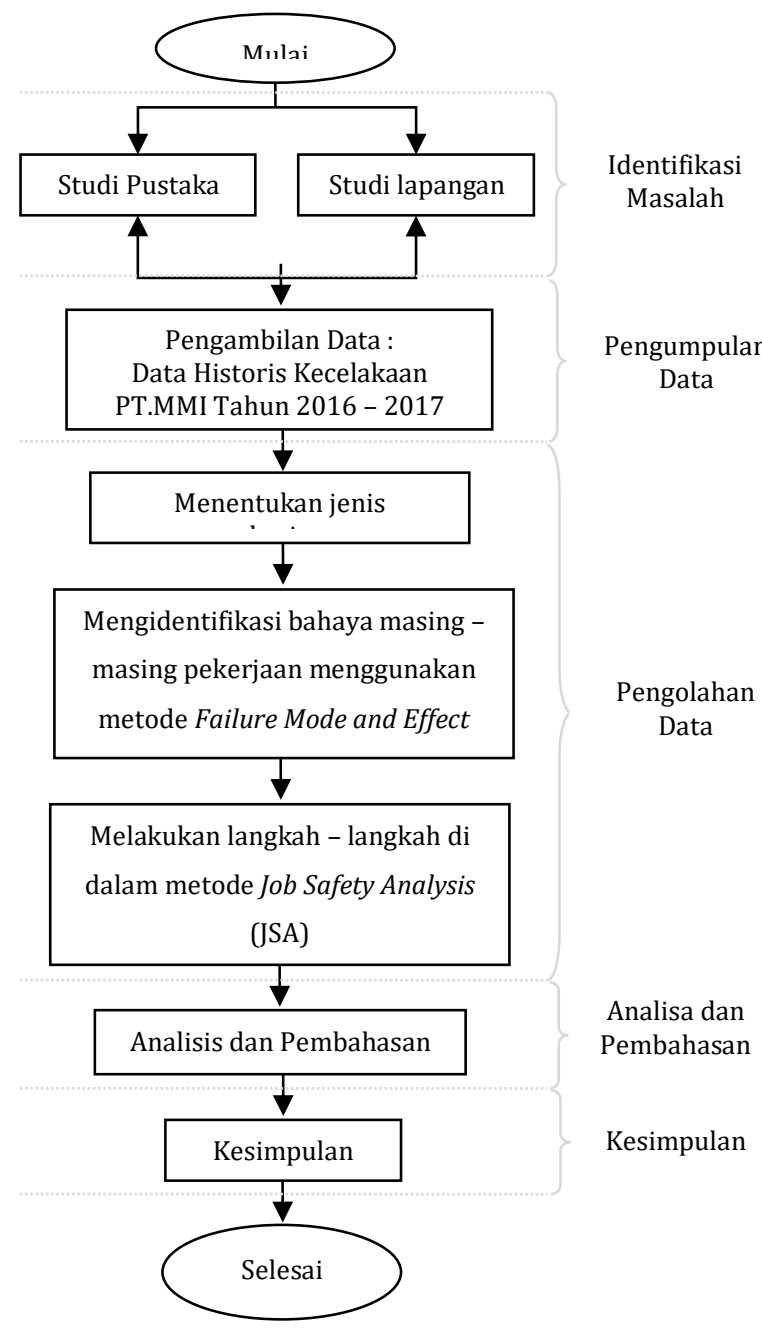

Gambar 1. Diagram alur penelitian

\section{HASIL DAN PEMBAHASAN}

Dari data kecelakaan kerja di PT. MMI Tahun 2016 - 2017 diketahui bahwa telah terjadi sebanyak 47 kali kasus kecelakaan yang terjadi. Kasus kecelakaan yang terjadi pada tahun 2017 lebih tinggi dibandingkan pada tahun 2016 dikarenakan kurang kehati - hatian karyawan dalam melakukan pekerjaan tersebut. 
Berikut data - data kecelakaan di PT. MMI Tahun $2016-2017$ :

Tabel 1. Data frekuensi kecelakaan kerja PT. MMI Tahun 2016 - 2017

\begin{tabular}{|c|c|c|}
\hline Bask & BUESELATAVIES, & 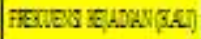 \\
\hline 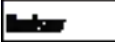 & 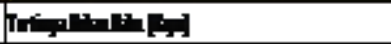 & $\mathbf{2}$ \\
\hline \multirow{3}{*}{ |' } & is & 5 \\
\hline & 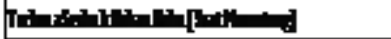 & 1 \\
\hline & |" & $\mathbf{1}$ \\
\hline |rit & 每 & $\mathbf{1}$ \\
\hline \multirow{6}{*}{ 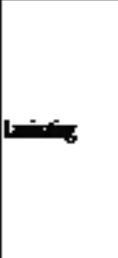 } & ] & $\mathbf{1}$ \\
\hline & if & 2 \\
\hline & 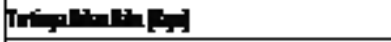 & 4 \\
\hline & 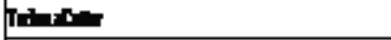 & 1 \\
\hline & 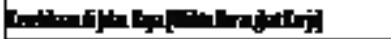 & $\mathbf{2}$ \\
\hline & 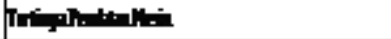 & 1 \\
\hline \multirow{3}{*}{ 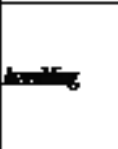 } & 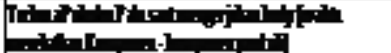 & $\mathbf{1}$ \\
\hline & ] & $\mathbf{1}$ \\
\hline & 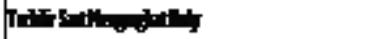 & 1 \\
\hline \multirow{4}{*}{ 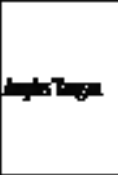 } & & $\mathbf{1}$ \\
\hline & 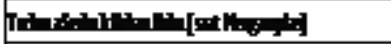 & 1 \\
\hline & 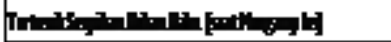 & 2 \\
\hline & 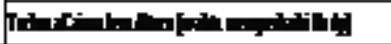 & 1 \\
\hline \multirow{5}{*}{$f^{2}$} & & 1 \\
\hline & 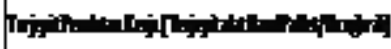 & $\mathbf{1}$ \\
\hline & 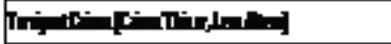 & $\mathbf{3}$ \\
\hline & 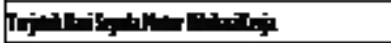 & 1 \\
\hline & 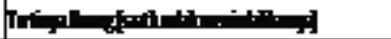 & $\mathbf{3}$ \\
\hline \multirow{3}{*}{ 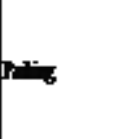 } & 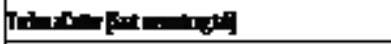 & 2 \\
\hline & 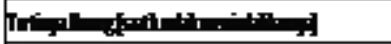 & $\mathbf{2}$ \\
\hline & & $\mathbf{1}$ \\
\hline & 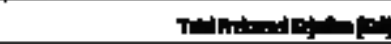 & 9 \\
\hline
\end{tabular}

Sumber : Data kecelakaan kerja PT. MMI tahun $2016-2017$

Pada pengolahan data ini yaitu tahapan dari pengolahan data menggunakan metode Failure mode and effect analysis (FMEA) yang selanjutnya akan dicari Failure Mode yang diprioritaskan untuk segera ditangani oleh PT. MMI dan dikemabngkan lagi menggunakan metode Job Safety Analysis (JSA)

\section{Tahap Failure Mode and Effect Analysis (FMEA)}

Failure mode diperoleh dari kategori kecelakaan yang telah terdapat pada data kecelakaan kerja PT. MMI tahun 2016 - 2017, berikut ini kategori kecelakaan :

1. Tertimpa Bahan Baku (Kayu)

2. Tekena Serbuk Bahan Baku (Saat memotong)

3. Terkena Cutter

4. Terjepit Mesin (Saat hendak membersihkan mesin)
5. Terciprat Cairan (Thiner Atau Lem Alteco )

6. Kecelakaan dijalan raya (Waktu Berangkat Maupun Pulang kerja)

7. Tertimpa Peralatan Mesin

8. Terkena pukulan palu saat mengerjakan body (Waktu Merekatkan komponen komponen body)

9. Terkilir saat mengangkat body

10. Terkena Mesin Amplas

11. Tertusuk serpihan bahan baku (Saat Mengamplas)

12. Terkena Meteran yang lepas

13. Terjepit Peralatan Kerja (Terjepit alat HandPallet/Dongkrak)

14. Terjatuh Dari Sepeda Motor dilokasi Kerja

15. Tertimpa Barang (saat hendak memindahkannya)

Mengidentifikasi Severity (Keparahan) yang terjadi

Severity adalah penilaian seberapa buruk atau serius dari pengaruh bentuk kegagalan yang ada dengan nilai ratingnya adalah 1 sampai 10 (Cayman Business System. Page 81-83)

Tabel 2. Dibawah ini akan menjelaskan tentang penelitian penilaian tingkat keparahan (Severity) yang terjadi pada proses produksi PT. MMI.

Tabel 2. Hasil penelitian penilaian failure mode terhadap severity yang diakibatkan

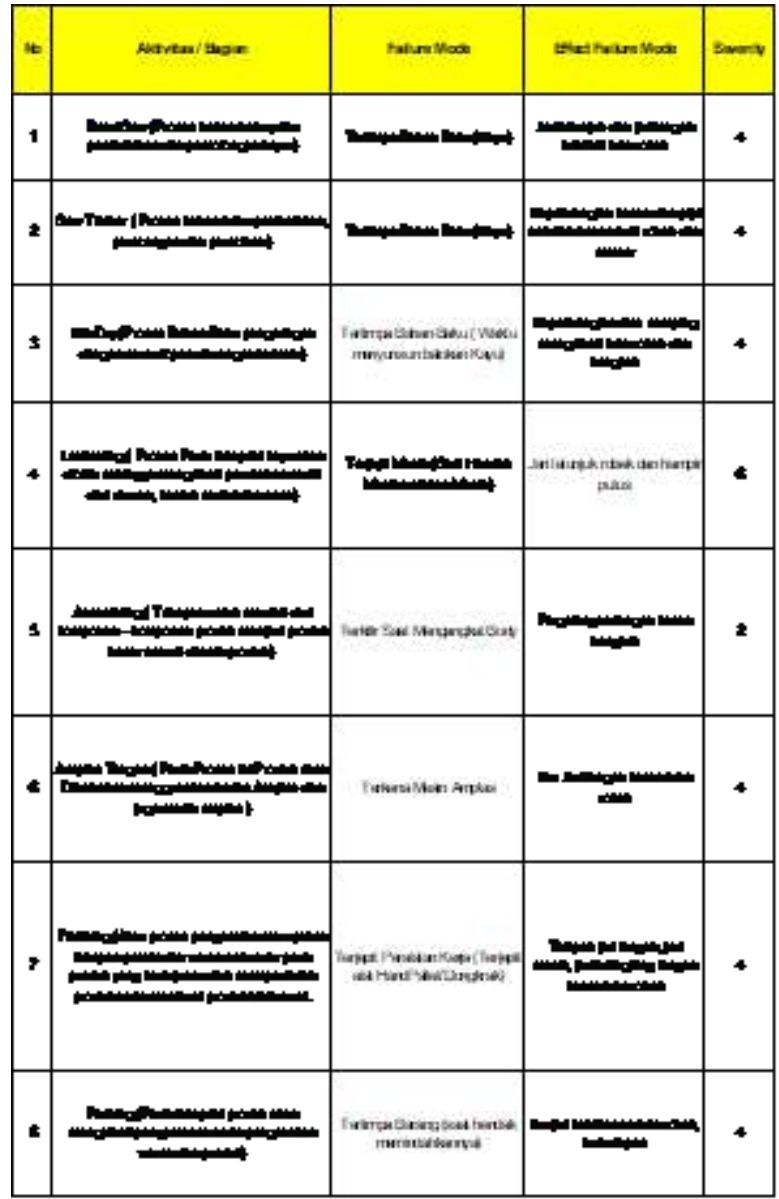


Berdasarkan tabel 2. Diatas nilai penentuan skala severity Terjepit Mesin (Saat Hendak Membersihkan Mesin) memiliki nilai severity tertinggi yaitu 6. Hal ini karena Failure mode Terjepit mesin memiliki dampak tingkat luka yang cukup parah karena tangan korban terjepit mesin waktu hendak membersihkan ketika jam kerja selesai menimbulkan luka robek dan jari hampir putus.

\section{Mengidentifikasi Occurence yang terjadi}

Occurence merupakan frekuensi dari penyebab kegagalan dari suatu proyek tersebut dan menghasilkan bentuk kegagalan dengan rating 1 sampai 10 (Cayman Business System. Page 81-83) Tabel 3. Dibawah ini akan menjelaskan hasil penelitian penilaian Occurrence yang terjadi pada proses produksi PT. MMI

Tabel 3. Hasil penelitian penilaian Occurrence yang terjadi

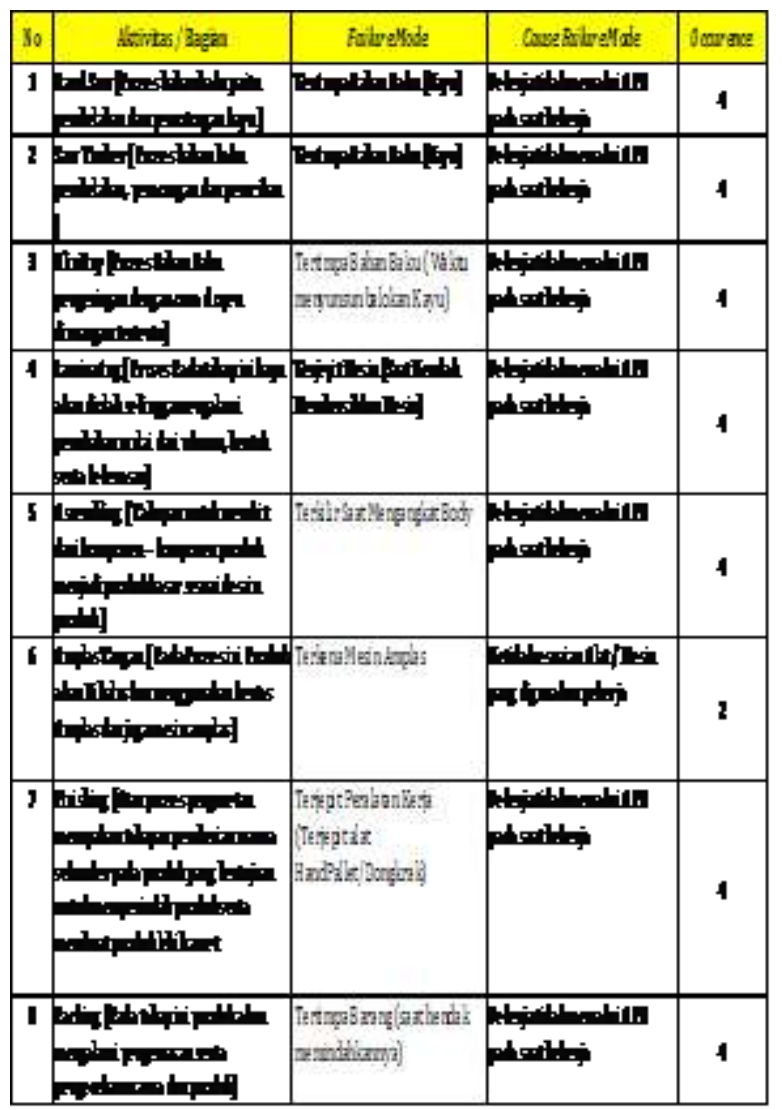

Berdasarkan hasil penentuan nilai ranking occurance dari cause of failure nilai Pekerja yang tidak memakai APD dengan lengkap menjadi nilai occurance tertinggi yaitu sama - sama memiliki nilai ranking 4 .

\section{Mengidentifikasi Detection penyebab terjadinya failure mode}

Pada langkah penelitian identifikasi alat untuk mendeteksi penyebab terjadinya failure mode, maka langkah selanjutnya adalah mengumpulkan data informasi untuk mengendalikan keberadaan Cause of failure yang menyebabkan terjadinya kecelakaan kerja.

Hasil penelitian penilaian ini didapatkan atas wawancara dari pihak - pihak yang berkepentingan diperusahaan (Manajer, Kepala bagian, Ketua regu, Pekerja itu sendiri, Petugas K3 yang ada di perusahaan dan Kepala maintenance/ Engineer).

Tabel 4. Berikut ini akan menjelaskan hasil penelitian penilaian detection penyebab terjadinya failure mode

Tabel 4. Hasil penelitian penilaian Detection yang terjadi

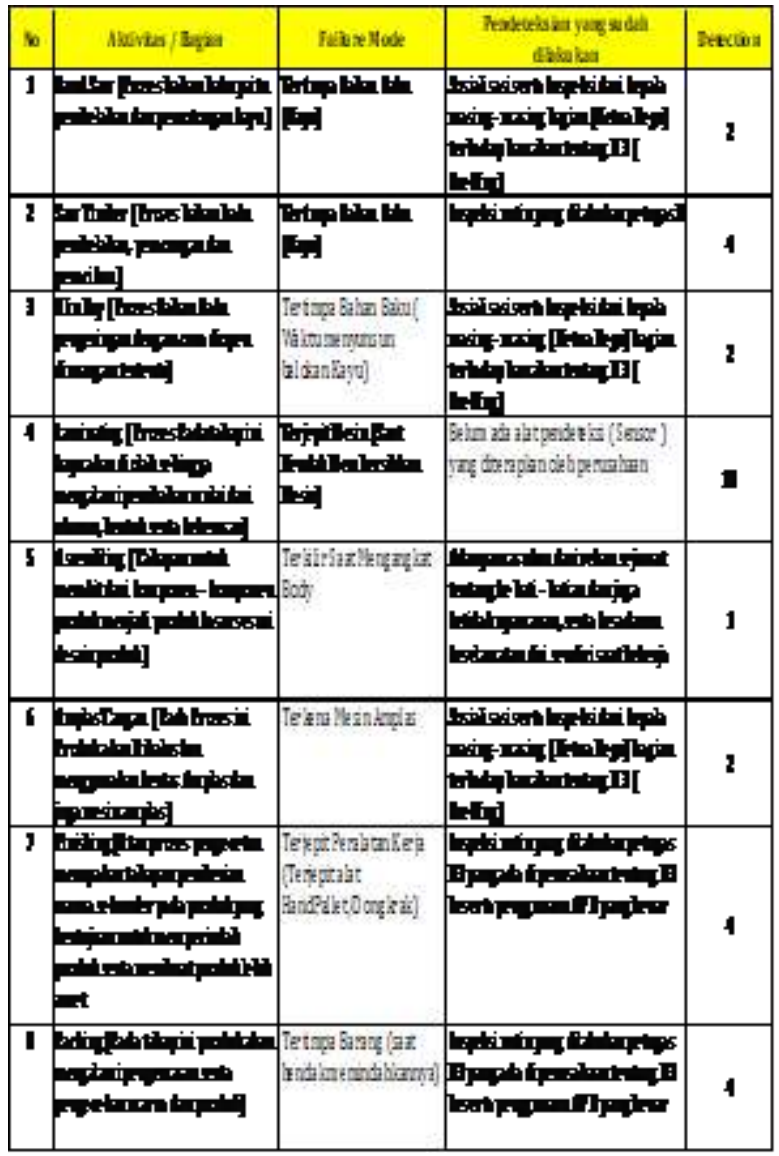

Untuk hasil anlisis FMEA mengenai Detection, failure mode pada Cause of failure yaitu Terjepit mesin Waktu membersihkannya karena Belum adanya alat pendeteksi (Sensor) yang diterapkan oleh perusahaan pada setiap mesin memiliki nilai detection tertinggi yaitu 10 .

\section{Perhitungan Risk Priority Number (RPN)}

Setelah didapatkan hasil penilaian Severity (S), Occurance (0), Detection (D) dari masing masing kegagalan, langkah berikutnya yaitu menentukan nilai RPN. Dengan tujuan dilakukan perhitungan nilai RPN yaitu untuk mengetahui urutan Failure mode yang harus diprioritaskan 
untuk ditangani terlebih dahulu.nilai RPN didapatkan dari perkalian antara Severity, Occurance, dan Detection.

$$
\mathrm{RPN}=\mathrm{S} \times \mathrm{O} \times \mathrm{D}
$$

Contoh perhitungan RPN pada kasus kecelakaan kerja pada departemen Band Saw yaitu Jari telunjuk dan jari tengah kaki kiri luka robek dengan nilai severity sebesar 4, nilai occurance sebesar 4 karena faktor Pekerja kurang berhati hati dalam melakukan pekerjaan (Kelalaian pekerja) hal ini terjadi 30 kali dalam dua tahun terakhir, serta nilai Detection sebesar 2 karena Sosialisasi serta inspeksi dari kepala masing masing bagian (ketua regu) terhadap bawahan tentang K3 (breffing).

Tabel 5. Hasil Perhitungan Penilaian RPN

\begin{tabular}{|c|c|c|c|c|c|}
\hline \multirow{2}{*}{ No } & \multirow{2}{*}{ Aktivitas/Bagian } & \multicolumn{3}{|c|}{ Risk Matriks } & \multirow{2}{*}{ RPN } \\
\hline & & $\mathbf{S}$ & 0 & D & \\
\hline 1 & Band Sar & 4 & 4 & 2 & 32 \\
\hline 2 & Sow Timber & 4 & 4 & 4 & 64 \\
\hline 3 & Klin Dry & 4 & 4 & 2 & 32 \\
\hline 4 & Lamin-ting & 6 & 4 & 10 & 240 \\
\hline 5 & Acoenthling & 2 & 4 & $\mathbf{1}$ & $\mathbf{8}$ \\
\hline 6 & Amplex Tangan & 4 & $\mathbf{2}$ & $\mathbf{2}$ & 16 \\
\hline 7 & Finizhing & 4 & 4 & 4 & 64 \\
\hline 8 & Parking & 4 & 4 & 4 & 64 \\
\hline
\end{tabular}

Dari hasil perhitungan tabel diatas telah didapatkan nilai RPN untuk masing - masing Departemen/bagian di PT.MMI, dan selanjutnya dikemas dalam bentuk chart seperti dibawah ini :

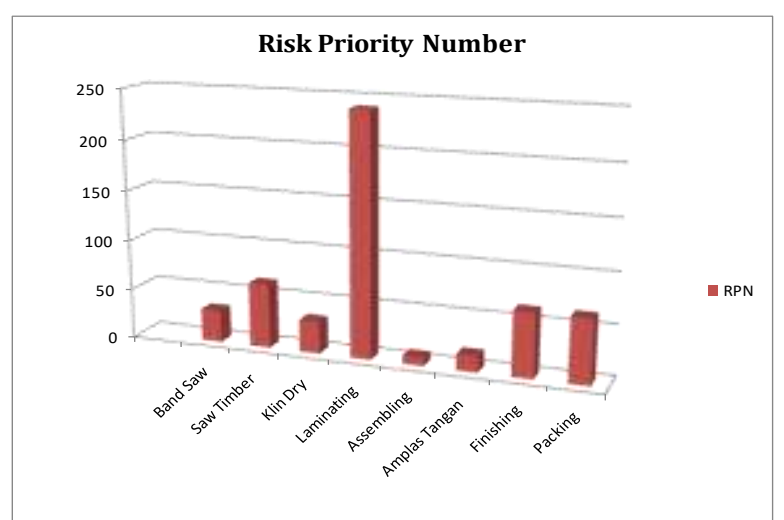

Gambar 2. Chart perhitungan penilaian RPN

Tujuan akhir dari metode FMEA adalah mengetahui nilai RPN yang tertinggi yaitu Terjepit Mesin (Saat Hendak Membersihkan Mesin) dengan nilai:

$$
\begin{gathered}
\mathrm{S}=6,0=4, \mathrm{D}=10 \\
\mathrm{RPN}=\text { Severity } \times \text { Occurance } \times \text { Detection } \\
=6 \times 4 \times 10=240
\end{gathered}
$$

Dengan Effect failure mode Jari telunjuk robek dan hampir putus terjadi pada bagian Laminating, Untuk tertinggi kedua dengan nilai RPN $=64$ yaitu Tertimpa Bahan Baku (Kayu) dengan Effect failure mode Kepala bagian kanan dan pipi sebelah kanan kulit robek dan memar terjadi pada bagian Saw timber.

Sedangkan tertinggi ketiga dengan nilai rata - rata RPN = 64 juga yaitu Tertimpa Barang (saat hendak memindahkannya), dengan Effect failure mode Kuku Ibu Jari kaki kiri mengelupas dan juga kepala mengalami luka robek serius terjadi pada bagian Finishing.

\section{Tahap Job Safety Analysis (JSA)}

Dalam pelaksanaan JSA terdapat beberapa tahapan langkah dasar yang harus dilakukan :

Berikut ini adalah Tahapan langkah - langkah dasar Job Safety Analysis (JSA) (Fauzi, 2009):

\section{Menentukan suatu pekerjaan yang akan dianalisis}

Terdapat 47 jenis kecelakaan kerja pada tahun 2016 - 2017 di PT. MMI yang dapat teridentifikasi pada area produksi, dengan total 22 kasus kecelakaan pada tahun 2016, dan 25 kasus kecelakaan pada tahun 2017

Berdasarkan perhitungan nilai rating RPN pada metode FailureMode and Effect Anlaysis (FMEA) terdapat 3 pekerjaan dengan potensi kerugian berupa kecelakaan kerja.

3 pekerjaan tersebut ialah pekerjaan menggunakan saw blade pada bagian saw timber, Pekerjaan pada Bagian Laminating yang menggunakan mesin press, dan juga pekerjaan pada bagian Finishing yaitu bagian terakhir dari proses perusahaan Furniture sebelum masuk ke bagian packing.

Menguraikan pekerjaan menjadi langkah dasar dan Mengidentifikasi Bahaya Pada Masing masing Pekerjaan

Untuk langkah selanjutnya yaitu dibuatkannya tabel worksheet Job Safety Analysis yaitu dimana tabel worksheet JSA ini berisi tentang Basic Job Step, Equipment, Potential Accidents Hazard, dan juga Recomnded safe procedure , dimana data - data ini diperoleh dari hasil wawancara dengan Koordinator Lapangan, Ketua Regu ( KR ) tiap bagian, Operator maintenance, petugas K3 dan juga pekerjanya secara langsung.

Berikut ini Tabel worksheet Job safety Analysis dimulai dari bagian yang paling awal yaitu saw timber, kemudian laminating dan untuk selanjutnya Finishing. 
Tabel 6. Worksheet Job Safety Analysis (JSA) Bagian Saw Timber

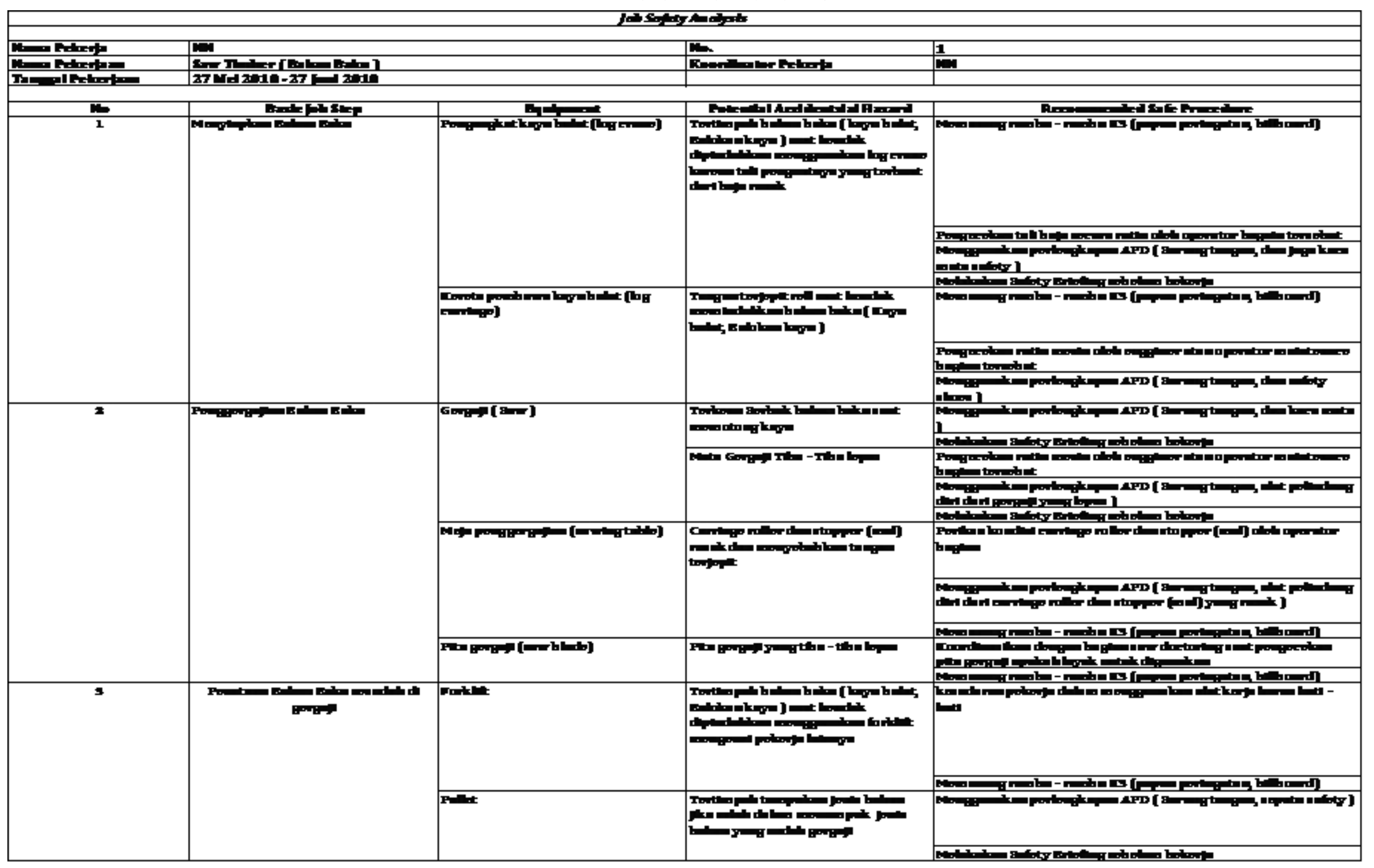


Tabel 7. Worksheet Job Safety Analysis (JSA) Bagian Laminating

\begin{tabular}{|c|c|c|c|c|}
\hline \multicolumn{5}{|c|}{ Job Safety Analysis } \\
\hline \multicolumn{2}{|c|}{ Nama Pekerja } & NN & No.: & 2 \\
\hline \multirow{2}{*}{\multicolumn{2}{|c|}{$\begin{array}{l}\text { Nama Pekerjaan } \\
\text { Tanggal Pekerjaan }\end{array}$}} & Laminating ( Melaminasi Komponen ) & Koordinator Pekerja & NN \\
\hline & & 27 Mei - 27 juni 2018 & & \\
\hline \multirow{4}{*}{$\frac{\text { No }}{1}$} & Basic Job Step & Equipment & Potential Accidentzial Hazard & Recommended Safe Procedure \\
\hline & \multirow[t]{3}{*}{ Menyiapkan bahan - bahan } & $\begin{array}{l}\text { Acuan (Standart Mall komponen) spesifikasi } \\
\text { pekerjaan disiapkan agar hasil pekerjaan sesuai } \\
\text { dengan kualitas }\end{array}$ & 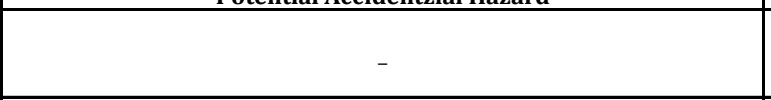 & 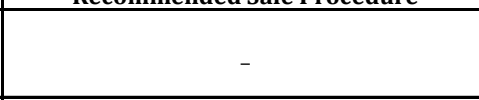 \\
\hline & & $\begin{array}{l}\text { Jenis bahan (Kayu solid, Manufactured board, } \\
\text { Shyntetic Solid ) dan jumlah komponen } \\
\text { disiapkan berdasarkan acuan spesifikasi } \\
\text { pekerjaan ( kayu Harus Kering sebelum } \\
\text { dilaminasi }\end{array}$ & - & - \\
\hline & & $\begin{array}{l}\text { Lem laminasi disiapkan berdasarkan } \\
\text { persyaratan dan kebutuhan. }\end{array}$ & $\begin{array}{l}\text { Ketumpahan lem saat membawah lem atau menaruhnya ditempat yang } \\
\text { tidak rata }\end{array}$ & $\begin{array}{l}\text { Menggunakan celemek agar kalau } \\
\text { ketumpahan lem tidak terkontak langsung } \\
\text { dengan kulit }\end{array}$ \\
\hline \multirow[t]{3}{*}{2} & \multirow{3}{*}{$\begin{array}{l}\text { Pengolesan jenis bahan ( Kayu solid, Manufactured } \\
\text { board, Shyntetic Solid ) dengan menggunakan Lem } \\
\text { laminasi }\end{array}$} & $\begin{array}{l}\text { Dengan peralatan Manual ( Kuas dan Papan } \\
\text { Laminasi ) }\end{array}$ & jika lem mengenai kulit, kulit akan iritasi merah dan gatal - gatal & $\begin{array}{l}\text { Menggunakan perlengkapan APD ( Sarung } \\
\text { tangan dan celemek ) }\end{array}$ \\
\hline & & \multirow[t]{2}{*}{ LamınasI] } & \multirow[t]{2}{*}{$\begin{array}{l}\text { jika terjadi kerusakan mesin lem akan menyembur dan mengenai mata, } \\
\text { dan akan terjadi iritasi mata }\end{array}$} & $\begin{array}{l}\begin{array}{l}\text { Pengecekan mesin secara rutin setiap mesin } \\
\text { glue spreader dioperasikan }\end{array} \\
\end{array}$ \\
\hline & & & & $\begin{array}{l}\text { Menggunakan perlengkapan APD ( Sarung } \\
\text { tangan dan kacamata safety ) }\end{array}$ \\
\hline \multirow[t]{4}{*}{3} & \multirow[t]{4}{*}{$\begin{array}{l}\text { Perekatan Jenis Bahan ( Kayu solid, Manufactured } \\
\text { board, Shyntetic Solid ) }\end{array}$} & \multirow[t]{3}{*}{\begin{tabular}{|l|} 
Mesin Hot Press ( Mesin Perekat kayu dengan \\
temperatur panas untuk membuat struktur kayu \\
lapis tetap stabil, dan juga menghilangkan \\
kelebihan kelembaban lem)
\end{tabular}} & \multirow[t]{3}{*}{$\begin{array}{l}\text { Terkena panas heating plate, Menghirup asap hot press dan juga, } \\
\text { tangan Terjepit belt pre press }\end{array}$} & $\begin{array}{l}\text { Pengecekan rutin mesin oleh engginer atau } \\
\text { operator maintenace bagian tersebut } \\
\begin{array}{l}\text { Menggunakan perlengkapan APD ( Sarung } \\
\text { tangan, Masker, dll ) }\end{array} \\
\end{array}$ \\
\hline & & & & $\begin{array}{l}\text { Memasang ramburambu K3 (papan } \\
\text { peringatan, billboard) }\end{array}$ \\
\hline & & & & Melakukan Safety Briefing sebelum bekerja \\
\hline & & $\begin{array}{l}\text { Mesin Cold Press ( Merupakan Mesin Perekat } \\
\text { kayu dengan temperatur dingin digunakan } \\
\text { untuk menekan dan pra-molding untuk papan } \\
\text { kayu lapis, melamin papan, partikel board dan } \\
\text { sebagainya ) }\end{array}$ & Tangan Terjepit belt pre press & \begin{tabular}{|l}
$\begin{array}{l}\text { Menggunakan perlengkapan APD ( Sarung } \\
\text { tangan, Masker, dll) }\end{array}$ \\
$\begin{array}{l}\text { Memasang ramburambu K3 (papan } \\
\text { peringatan, billboard) }\end{array}$ \\
Melakukan Safety Briefing sebelum bekerja \\
\end{tabular} \\
\hline 4 & $\begin{array}{l}\text { Penataan Jenis bahan Yang sudah melalui proses Press } \\
\text { di atas pallet - pallet Yang tersedia }\end{array}$ & Pallet Besi dan Pallet Kayu & $\begin{array}{l}\text { Tertimpah tumpukan Jenis bahan jika salah dalam menumpuk jenis } \\
\text { bahan yang sudah dipress }\end{array}$ & \begin{tabular}{|l}
$\begin{array}{l}\text { Menggunakan perlengkapan APD ( Sarung } \\
\text { tangan, sepatu safety) }\end{array}$ \\
Melakukan Safety Briefing sebelum bekerja
\end{tabular} \\
\hline
\end{tabular}


Tabel 8. Worksheet Job Safety Analysis (JSA) Bagian Finishing

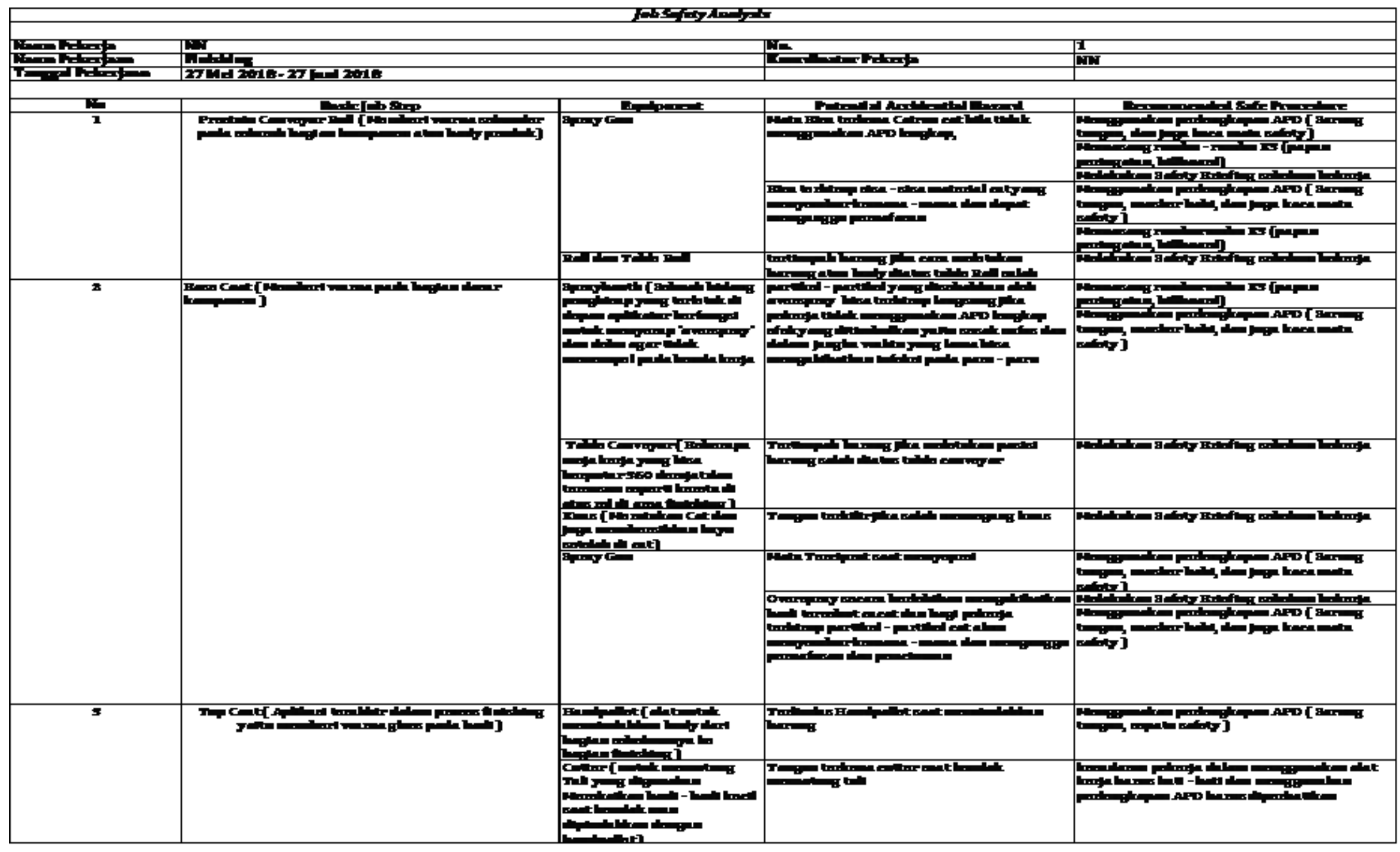




\section{PENUTUP}

Berdasarkan hasil pengamatan, pengolahan dan analisa data dapat disimpulkan sebagai berikut :

1. Potensi bahaya yang terdapat pada setiap departemen PT.MMI adalah sebagai berikut : untuk potensi bahaya pada departemen Band Saw adalah tertimpa bahan baku (kayu), potensi bahaya pada departemen Saw Timber adalah Tertimpa bahan baku (kayu), Terkena serbuk bahan baku (saat Memotong), dan Terkena Cutter, potensi bahaya pada departemen Klin dry adalah Tertimpa Bahan baku (Waktu menyunsun balokan kayu), potensi bahaya pada departemen Laminating adalah Terjepit Mesin, Terciprat cairan (Oli Mesin), Tertimpa Bahan Baku (kayu), Terkena Cutter dan Tertimpa peralatan Mesin, Untuk departemen Assembling potensi bahaya yang ditimbulkan adalah Terciprat cairan (Lem Alteco), Terkena Pukulan palu saat mengerjakan bodi (waktu merekatkan komponen - komponen produk), selanjutnya potensi bahaya pada bagian Amplas tangan adalah Terkena mesin amplas, terkena serbuk bahan baku (saat mengamplas), tertusuk serpihan bahan baku (saat mengamplas), Terkena cairan lem Alteco, untuk departemen Finishing potensi bahayanya adalah Terjepit peralatan kerja (Handpallet), Terciprat cairan (lem alteco, thiner), dan tertimpa barang, dan pada departemen yang terakhir yaitu Packing potensi bahaya yang ditimbulkan adalah Tertimpa barang (saat hendak memindahkannya) dan terkena cutter (saat memotong tali).

2. Dari hasil perhitungan nilai Risk Priority Number (RPN) dapat diketahui bahwa failure mode atau aktivitas pekerjaan yang harus ditangani perusahaan terlebih dahulu adalah Pada Departemen Atau Bagian Laminating karena berdasarkan data kecelakaan kerja PT. MMI dibagian tersebut terdapat kecelakaan kerja dengan kategori Terjepit Mesin, Kategori ini adalah kategori kecelakaan kerja yang terjadi pada saat pekerja selesai bekerja dan pada saat mesin dimatikan seketika itu pekerja membersihkan mesin tersebut dan tanpa sepengatuhan, mesin masin menyala dan tangan pekerja terjepit mesin tersebut, hal ini dapat terjadi karena belum diterapkannya alat pendeteksi (sensor) oleh perusahaan,Perincian Nilai RPNnya adalah sebagai berikut :

$\begin{array}{ll}\text { Nilai Severity } & : 6 \\ \text { Nilai Occurance } & : 4 \\ \text { Nilai Detection } & : 10 \\ \text { Nilai RPN } & : 240\end{array}$

3. Terdapat 3 bagian departemen yang pekerjaan atau aktivitasnya dianggap kritis memiliki resiko kecelakaan paling tinggi, ini dapat dianalisis menggunakan metode Job Safety Analysis (JSA). Pekerjaan tersebut adalah pekerjaan dengan Proses bahan baku pembelahan, peracangan dan peracikan dengan menggunakan alat Gergaji (Saw), Meja penggergajian (sawing table), Pita gergaji (saw blade), dan juga Pengangkat kayu bulat (log crane), selain itu pekerjaan Melaminasi Kayu dengan mesin glue spreader, Hot Press, dan juga Cold Press, dan pada pekerjaan yang dianggap bahaya ialah pada bagian finishing, Pekerjaan proses terakhir pada perusahaan furniture yaitu member warna dasar hingga warna glose pada body, pekerjaan ini berhubungan langsung dengan material cat yang disemprotkan langsung ke body menggunakan alat Spray gun tentu efek dalam pernafasan secara langsung bisa terganggu jika tidak menggunakan APD dengan benar dan lengkap, dan dalam jangka panjang bila tidak menggunakan APD dengan benar dapat terkena penyakit infeksi paru - paru saluran pernafasan.

4. Rekomendasi akhir untuk meminimalisir tingkat kecelakaan kerja pada area produksi PT.MMI adalah dengan menyunsun Intruksi Kerja (IK) sesuai dengan metode JSA yang berisi tentang penggunaan alat pelindung diri (APD) yang dibutuhkan, potensi bahaya apa saja yang dihadapi, serta tindakan apa selanjutnya yang diperlukan untuk mengantisipasi potensi bahaya yang bisa saja muncul kapan saja.

Berikut ini adalah saran - saran yang dapat diberikan kepada perusahaan yang berkaitan dengan tindakan lanjutan perusahaan untuk menanggulangi kecelakaan kerja dan juga kemungkinan studi di masa mendatang :

1. Perbaikan materi pelatihan dan cara penyampaiannya oleh Petugas K3, Manajer, Koordinator bagian dan juga supervisor tentang Keselamatan dan kesehatan kerja (K3),dan penggunaan atribut APD lengkap dan benar, sehingga pekerja lebih bisa menerima dan menyerap materi pelatihan yang diberikan, dengan begitu pekerja tidak menganggap pelatihan hanyalah formalitas semata, selain itu juga dengan perbaikan materi pelatihan pekerja mampu bekerja sesuai dengan prosedur kerja yang ada dan dapat dilakukan dengan maksimal.

2. Untuk penelitian selanjutnya adalah penambahan metode yang lebih spesifikkan lagi tentang K3 yang bertujuan sebagai tindakan identifikasi bahaya dasar demi mendapatkan perbaikan yang konsisten, selain itu juga diharapkan dapat membantu perusahaan dalam pembuatan sanksi hukuman 
bagi para pekerja yang melanggar rambu rambu K3 serta tidak menggunakan Atribut APD yang lengkap sesuai dengan Sistem Manajemen Keselamatan dan Kesehatan Kerja (SMK3)

\section{DAFTAR PUSTAKA}

Failure Mode and Effect Analysis. 2002. Cayman Business System. Page 81-83.

Fauzi, S. A. 2009. Job safety Analysis Sebagai Langkah Awal dalam Upaya Pencegahan Terjadinya Kecelakaan Akibat Kerja di Area Attachment Fabrication PT. Sanggar Sarana Baja Jakarta Timur, Tugas Akhir, Teknik Industri, Universitas Negeri Surakarta, Surakarta.
Levi (2017). Usulan Perbaikan Keselamatan Kerja Menggunakan Metode Job Safety Analysis (JSA) dan Failure Mode and Effet Analysis (FMEA). Spektrum Industri Vol. 15, No. 2, Universitas Ma Chung, Malang

Rijanto, B., 2010,Pedoman Praktis Keselamatan, Kesehatan Kerja dan Lingkungan (K3L), Mitra Wacana Media, Indonesia.

Siswanto, Y., 2010. Perancangan Preventive Maintenance Berdasarkan Metode Reliability Centered Maintenance Pada PT. Sinar Sosro, Tugas Akhir, Teknik Industri, Universitas Sumatera Utara, Medan.8 